\title{
Mérföldkövek a máj sebészetében
}

\author{
Jakab Ferenc dr. \\ Uzsoki Utcai Kórház, a Semmelweis Egyetem Oktató Kórháza, Sebészeti Osztály, Budapest
}

\begin{abstract}
Az ezredfordulót követően számos összefoglaló közlemény látott napvilágot mind a hazai, mind a nemzetközi szakirodalomban a májsebészet XX. századi mérföldköveit, vagyis fejlődésének meghatározó tényezőit illetően. Ezért a jelenlegi összefoglalás a gyorsan fejlődő májsebészetből csak a legújabb elvek és innovációk bemutatására szorítkozik, a legtöbb érdeklődést kiváltóak kerülnek górcső alá: a legújabb indikációk, a kirekesztés-vértelenség kérdése, a májregenerációt a mai tudásunk és az evidenciák szerint a legnagyobb mértékben elősegítő legújabb beavatkozás, a májszétválasztás kétszakaszos májreszekcióban portalis elzárással, továbbá a daganatok „downsizing” kezelése a korábban reszekálhatatlan daganatok eltávolítása érdekében. A nyitott májsebészet, a laparoszkópos és a robotmájsebészet összehasonlításában megfogalmazható az a tény, hogy a laparoszkópos májsebészet napjainkban vált választható beavatkozássá, és bizonyos területeken már jobb eredmények érhetők el vele, mint nyitott mütéttel. A robotmájsebészetben szerzett adatok és a bizonyítékok máig váratnak a helyes következtetés levonására. A májsebészet egészét tekintve a mortalitás jelentősen csökkent (1\%), s a szövődmények - nagyfokú heterogenitásuk miatt - nehezen hasonlíthatók ugyan össze, de a nemzetközi törekvés igyekszik közös nevezőt kialakítani a módosított Clavien-Dindorendszer, a módosított Accordion-rendszer, valamint a komprehenzív komplikációs index fogalmának létrehozásával. A májsebészet országonként eltérő fejlettségben, de komplex módon kapcsolódik a tápcsatorna-, a hepatopancreatobiliaris, a transzplantációs és az onkológiai sebészethez. A májsebészet korszerú fogalma multidiszciplináris, multimodális követelményrendszert tartalmaz a májbetegségek megközelítéséhez, amelynek célja a legeredményesebb kezelés biztosítása. Megállapítható, hogy napjainkra a májsebészet szuperspecializációvá vált a nemzetközileg is észlelhető jelentős fejlettségi különbségek ellenére, amelyek kiegyensúlyozása egyébként összhangban van az egészségügy nemzeti, kontinentális és globális szintű erőfeszítéseivel az egyenlőtlenségek felszámolására.
\end{abstract}

Orv Hetil. 2018; 159(10): 375-383.

Kulcsszavak: májsebészet, nyitott, laparoszkópos és robotmájsebészet, primer és szekunder májtumor, májregeneráció, kirekesztés-vértelenség, Pringle-manőver, „downsizing”, Clavien-Dindo-osztályozás, Accordion-szisztéma, komprehenzív komplikációs index, májsebészeti centrum, májsebészképzés-akkreditáció

\section{Milestones in liver surgery}

Numerous outstanding summarizing publications on the milestones of the rapid development of liver surgery in the twentieth century came to light around the year 2000, therefore in this summary only the newest principles and novelties of liver surgery after the second millennium are presented. Among the new principles, the newest indications, the bloodless surgery and the vascular exclusion of the liver, the "associating liver partition and portal vein occlusion for staged hepatectomy" (ALPPS) - as presently the fastest and most successful method for liver regeneration, and the "downsizing of tumors" treatment for the interest of resection of unresectable tumours are analyzed and evaluated. Open, laparoscopic, and robotic liver surgery are discussed by comparing blood loss, operating time, cost, and long-term results. Laparoscopic liver surgery on the basis of evidences has become "the method of choice" in our days. Robotic liver surgery needs further evidence-based data for determination of its place in the clinical practice. An intention is also composed in terms of place-determination of liver surgery between gastrointestinal, hepatopancreatobiliary, liver transplantation, and oncologic surgery. The mortality rate has decreased to $1 \%$ recently; the data regarding morbidity are variable; the modified Clavien-Dindo, the modified Accordion complication system and the comprehensive complication index are intended to move the different evaluations to a common ground. The up-to-date idea of hepatic surgeon, liver center and liver surgery are defined in close cooperation with international theoretical and practical outcome, in the limelight of multidisciplinarity and multimodality. The internationally observed inequalities in liver surgery are also discussed from the point of view of tackling with the inequalities existing in the universal healthcare systems on a local, national and global level by collecting and controlling the results systematically, and developing and implying international guidelines on the basis of evidences. 
Keywords: liver surgery, vascular exclusion/Pringle maneuver, downsizing of tumors, liver regeneration, ALPPS, open, laparoscopic, robotic-hepatic surgery, comprehensive complications index, hepatic surgeon, inequalities in liver surgery, international consensus guidelines

Jakab F. [Milestones in liver surgery]. Orv Hetil. 2018; 159(10): 375-383.

Semmelweis Ignác születésének 200. évfordulója évében a Szerkesztőség felkérésére készített tanulmány.

(Beérkezett: 2017. december 18.; elfogadva: 2018. január 16.)

\section{Rövidítések}

ALPPS $=$ associating liver partition and portal vein ligation for staged hepatectomy; BCLC $=($ Barcelona Clinic Liver Cancer $)$ barcelonai kritériumok; $\mathrm{CCI}=($ Comprehensive Complications Index) komprehenzív komplikációs index; CUSA = Cavitron ultrasonic aspirator; DFS $=$ (disease-free survival) betegségmentes túlélés; HAF $=$ hepatic arterial flow; HCC $=$ hepatocellular cancer; MELD = Model for End-Stage Disease; NCNNLM = (non-colorectal non-neuroendocrine liver metastasis $)$ nem colorectalis eredetű májáttét; $\mathrm{OS}=($ all over survival $)$ teljes túlélés; PEI = percutaneous ethanol injection/infiltration $; \mathrm{PVF}=$ portal venous flow $\mathrm{RCT}=($ randomized controlled trial) randomizált kontrollált vizsgálat; $\mathrm{RFA}=$ radiofrequency ablation; SFSS $=$ small for size syndrome; WHO $=($ World Health Organization) Egészségügyi Világszervezet

Az 1954-es és az 1957-es évszámok jelzik Conineaud közleményeit a szegmentális májanatómiáról. Ugyan csak negyed évszázad után vált általánossá és nemzetközileg használttá, de innen számíthatjuk a modern májsebészeti érát. Számos, a májsebészeti fejlődést összefoglaló közlemény jelent meg a közelmúltban [1-9]. Történetileg a sérülések játszottak szerepet a májsebészet létrejöttében és fejlődésében - sajnos e területen, legalábbis a gyakoriságot illetôen, nincs változás. A máj kettős afferens keringése, a vena hepaticák és a vena cava inferior bőséges vérhozama miatt az e területen bekövetkező áthatoló vagy tompa trauma rövid időn belül végzetes lehet! [10] Az elmúlt évtizedekben meghatározó volt a szegmentális anatómia kidolgozása a „máj sebészeti anatómiájáról”, amely az „anatómiai májsebészet” alapja $[8,9]$. A májkeringés kutatása kiemelkedően eredményes volt, hiszen a máj artériás és portalis vénás keringésének (HAF/PVF) kölcsönhatásából diagnosztikai következtetések levonása is lehetségessé vált, és ismeretessé vált az is, hogy milyen fontos szerepet tölt be a portalis véna ágának elzárása a májregenerációban, továbbá hogyan változik a daganatos máj keringése, valamint a reszekált és a transzplantált máj cirkulációja [11]. Időközben a technikai fejlődés az ultrahangos (UH-) készüléket behozta a mútőbe, és a mútét alatt végzett ultrahangvizsgálat a májon belüli „sebészi anatómiát” manapság úgy ábrázolja, hogy a májsebész számára lehetővé teszi az „anatómiai reszekciót”, tehát a Bismuth megfogalmazta elv („a máj anatómiai sebészete”) a tech- nikai fejlődés alapján valósult meg [12]. Napjainkban az intraoperatív ultrahangvizsgálat a májmútét szerves tartozéka a kicsiny, nem gyanított daganatok felfedezésére, ső́t a colorectalis rák mútéte során - a jövő́be mutatóan - szứro jelleggel is ajánlják a májmetasztázisok felfedezésére [13]. A májkeringési vizsgálatok alapozták meg a portalis embolizációt/okklúziót és annak különböző módozatait. Az így előidézett jelentős fokú májregeneráció miatt az elsődleges vagy másodlagos daganatok miatti reszekció határai messze kitolhatókká váltak, sőt akár a máj mindkét lebenyében lévő daganatok múthetővé váltak speciális esetekben [14].

A technikai fejlődés szervesen és folyamatosan beépült a májsebészetbe a diagnosztika és a vérzéscsillapítás vonatkozásában. Az 1990-es évektól kezdve a minimálisan invazív beavatkozás alapelve a laparoszkópos májsebészetben került megvalósításra. Ez az integrációs folyamat tipikusan jellemzi az elvek, a társszakmák és a technika ölelkezését a multimodális, mind jobb eredményeket felmutató, evidenciaalapú multidiszciplinaritás irányában $[15,16]$. Időközben a májtranszplantáció rohamos fejlődése és elterjedése jelentősen kihatott a májsebészetre is, és ma a két terület elválaszthatatlanul összefonódik számos vonatkozásban [7]. A gyors fejlődésben a digitalizáció átszövi a kezdetben szinte eszköztelen, csupán néhány múszerrel dolgozó májsebészetet, létrehozva a ma már valóságos és összehasonlítható eredményeket felmutató, robottal végzett beavatkozásokat a májon [17]. Ezért lehet eljutni arra a megállapításra, hogy a májsebészet - integrálódva számos medicinális szakmával (képalkotó diagnosztika, hepatopancreatobiliaris sebészet, gasztroenterológia, aneszteziológia, onkológia, transzplantológia, patológia stb.) szuperspecializációvá vált.

\section{Indikáció}

Az elsődleges és a másodlagos daganatok műtéti indikációja megváltozott az onkológiai és a májsebészeti fejlődés, valamint az eredmények és a betegbiztonság javulásának következtében. Az egymás után megjelenő közlemények a mortalitás és a morbiditás csökkenéséről és a túlélés jelentős meghosszabbodásáról számolnak be. Ezresnél nagyobb halálozás nélküli reszekciós széria is 
közlésre került. Így ma már állást lehet foglalni az 1\% vagy az az alatti halálozás és a 25-30\% alatti átlagos szövődményarány elvárható értékében $[1,2]$. Nagyon jót tett a májsebészet fejlődésének a májtranszlantációs gyakorlat innovációinak alkalmazása (split liver, dual graft, laparoszkópos donorszerv-kivétel, virtuális hepatectomia). Az élő donoros transzplantáció is komoly definiáló tényezővé vált $[7,18]$. Általánosságban az elsődleges és a másodlagos májdaganatok mütéti indikációjának megalapozottságát azonban nemcsak a rövid távú eredmény (morbiditás, mortalitás), hanem a hosszú távú túlélés, tehát az onkológiai kimenet is alapvetően befolyásolja. A májsebészetileg elérhető eredmények, sőt a májtranszplantáció nyújtotta lehetőségek, valamint az onkológiában (a betegszelekció új szempontjai, RAS- és BRAF-mutáció, kemoterápia és biológiaiválasz-módosítók) észlelhető elörelépés, hozzáadva a napjainkban is alapvető és meghatározó sebészi beavatkozásokkal elérhető eredményekhez, kialakították a „személyre szabott” indikációt a „személyre szabott” kezeléssel. Ebben a korszerü multidiszciplináris, multimodális szemléletben elsődleges vagy másodlagos májdaganat esetén az indikáció és a teendők sorának megállapítása ma már nem lehet egyetlen szakember feladata, hanem multidiszciplináris munkacsoport alakíthatja ki a kezelési stratégiát [3, 19].

A primer májdaganatok közül a hepatocellularis carcinoma (HCC) a malignus folyamatok közül az ötödik vámszedő az emberi élet ellen. A sebészi májreszekciók mintegy 10\%-a történik HCC eltávolítására. Nem kitérve az etiológiai, genetikai, patológiai tényezőkre, Nagasue után a sok százezer boncolás alapján tudjuk, hogy a HCC gyakran multiplex, a máj mindkét lebenyében megjelenhet, az epeutakba, a nyirokerekbe és a vénákba is (vena hepatica, v. cava inferior, jobb szívfél) betörhet. A vírushepatitisből kialakuló cirrhosis képezi a talajt a HCC kialakulására (hepatitis B: 350 millió beteg, hepatits C: 140 millió beteg). Az is ismeretes, hogy az ép májban is fejlődhet az elsődleges májrák, mintegy 10\%ban. Az indikáció 2000 előtt elsődlegesen a HCC eltávolítását célozta meg a májreszekció segítségével. A kiábrándító eredmények, a magas halálozási ráta és a korai kiújulás analízise azt eredményezte, hogy árnyaltabban kell felállítani az indikációt, figyelembe véve a HCC nagysága, jellegzetességei, stádiuma mellett a daganatot hordozó máj állapotát is (a vírushepatitisből kialakuló cirrhosis mértékét és a vascularis következmények előrehaladottságát) [20]! A barcelonai kritériumok (BCLC) szerint a korai HCC (maximum három göb, egyike sem haladja meg a $3 \mathrm{~cm}$ átmérőt) sebészi reszekcióval, májtranszplantációval, etanolablatióval/rádiófrekvenciás roncsolással kezelhető kuratíve a máj állapotától (fibrosis, cirrhosis, portalis hypertensio) függően, amelyek a Child-Pugh-stádiummal és a hepaticus vénás nyomásgradienssel objektivizálhatók [20]. Szoliter HCC esetében a reszekciós kritérium az $5 \mathrm{~cm}$-es daganatátmérő. Számos májcentrum gyakorlatában lényegesen nagyobb átmérőjüek is reszekcióra kerültek. A BCLC-irányelvek szerint szigorúan vett korai stádiumban a kuratív kezelés 5 éves túlélése 50-75\% [21]. A korai HCC kezelésére ajánlott májtranszplantáció a milánói kritériumok szigorú betartása mellett ( 1 maximum $5 \mathrm{~cm}$-es daganat vagy 3 tumor, de egyik sem haladja meg a $3 \mathrm{~cm}$ átméröt, és nincs ér-makroinvázió) kiváló $75 \%$ feletti 5 éves túlélést és alacsony recidívaarányt eredményez [22]. Az ún. „bridge-technikák” (RFA, PEI és bizonyos esetekben a májreszekció) jelentős segítséget jelentenek az indikációs folyamatban, főleg a májtranszplantációs várólistán lévők halálozásának csökkentésében, amely $20-25 \%$-ot is elérhet 6 hónap alatt. Manapság a HCC intermedier és előrehaladott stádiumában a kemoembolizáció és az új szerek (szorafenib) alkalmazása jön szóba. Bekerült a klinikumba az „up to seven” elv is, miszerint a tumorszám és az átmérő összege nem haladhatja meg a 7-es számot a sebészi beavatkozáshoz. A transzplantációs központok recipienskritériumai eltérhetnek ugyan egymástól, azonban közös nevezőt jelent a MELD (Model for End-Stage Disease) és az egyéb pontozásos rendszerek alkalmazása. Az „up to seven” elv egyébként az intraoperatív fénysebességü UH-nak is köszönhető, amelylyel akár 0,4 cm-es HCC kórismézhető. Mind a barcelonai, mind a milánói kritériumokat sok kritika érte, az időközben nemzetközi konszenzussal létrehozott Alberta-algoritmus viszont megengedőbb, rugalmasabb multidiszciplináris indikációs folyamatot tesz lehetôvé [23].

A colorectalis eredetű másodlagos májdaganatokat illetően az elmúlt 50 év bebizonyította, hogy a májáttétek eltávolítása az emberi élet jelentős meghosszabbodásához vezet a kuratív mútétet követően, minimálisan elvárható 40\%-os 5 éves túléléssel. A sebész 30-50 éve még magára volt utalva az indikáció felállításában, a májmútét kivitelezésében és a nyomon követésben. E területen az egyebekben meghatározó és elsődleges májsebészet sok segítséget kapott az onkológiától. A 21. század második évtizedének vége felé általános elvként kimondható, hogy a daganattal foglalkozó szaktudományok teljesítményének és egymásra utaltságának figyelembevételével multidiszciplináris onkosebészeti munkacsoport határozhatja meg az indikációs stratégiát [24]. A neoadjuváns és az adjuváns kezelés, valamint a sebészi beavatkozás ajánlásai ma már irányelvekben konkréten megfogalmazottak. A colorectalis eredetú szekunder májdaganatok kezelési stratégiája elsősorban a primer daganathoz való viszonytól (R0-reszekció, nincs recidíva) és a megjelenés idejétől függ, másodsorban attól, hogy eleve könnyen eltávolítható-e a májból, vagy ún. határeseti metasztázisról van-e szó, vagy éppen a felfedezésük időpontjában már eltávolíthatatlanok az áttétek sebészi vagy biológiai/onkológiai okból. Szemléletváltás van abban a kérdésben is, hogy nem a daganatok száma, nagysága és mennyisége számít, hanem az, hogy valamennyi daganatszövet eltávolításra kerüljön R0-módon, és elegendő, múködő májállomány maradjon (az eredeti májvolumennek legalább a 30\%-a vagy több). Az elegen- 
dő, mưködő májállomány az afferens és efferens keringés és az epeelválasztás és -passzázs megtartása mellett a májsejtmúködés funkcionális megmaradását jelenti. A szinkrón esetben onkológiai kezelés és a májmetasztázisok elsődleges eltávolítása („liver first”) is lehetséges, majd később a primer daganat eltávolítása (R0), ha ez utóbbi nem jár ileusveszéllyel [25]. A májmetasztázisok onkosebészi kezelése diadalutat járt be olyan területeken, amelyeken korábban nem is indikálták a májmetasztázisok eltávolítását, ideértve a nem colorectalis eredetú májáttétek (NCNNLM) egy részét is, sőt a májmetasztázissal egyidejű extrahepaticus áttétek sebészetét is [26, 27]. Az onkológiai neoadjuváns és adjuváns kezelés, felhasználva a molekuláris diagnosztika eredményeit (KRAS, BRAF) és klinikai vonatkozásait (biológiaiválaszmódosítók: bevacizumab, cetuximab, panitumumab), a mưtét utáni hosszú távú túlélés eredményein szignifikánsan javított! Az onkológiai kezelésre létrejövő daganatmegkisebbedés alapján kialakult a „jó választ” adó, kezelésre reagáló beteg fogalma [28].

A „borderline”-típusú áttétek esetében a neoadjuváns kezelés célja a daganat olyan fokú megkisebbedése/ megkisebbítése („downsizing”), hogy a reszekció kivitelezhető legyen. Lényeges leszögezni, hogy ezen előbbi kategóriák az újabb felfedezések és szemlélet birtokában országonként, sőt centrumonként is változhatnak, még ha a nemzetközi és a nemzeti irányelvek sztenderdizációs törekvése kifejezett is. A „borderline”-típusú, vagyis a potenciálisan reszekálható daganat esetén a biológiaiválasz-módosítókkal (bevacizumab, cetuximab, panitumumab) végzett neoadjuváns kezelés, az ún. konverziós terápia mintegy 15-40\%-ban lehetővé teszi a korábban reszekálhatatlan áttét eltávolítását, sőt néha a daganat(ok) eltünése még sebészi gondot is okozhat az áttét helyének fellelésében [12].

A „borderline”-típusú, vagyis potenciálisan reszekálható, határeseti daganat eltávolításának másik, forradalmian új lehetősége a múködő májszövet mennyiségének növelése. A májelégtelenség veszélyével fenyegető túl kicsiny, jövőbeli májresiduum (SFSS) megoldására kidolgozásra került a vena portae ág lekötése (a vena portae ág embolizációja) a beavatkozást követő azonos oldali, bennmaradó májrészt érintő nagymértékű májregenerációval. A kétszakaszos májreszekció, valamint a portalis ág embolizációja kombinált májszétválasztással (ALPPS) a máj mindkét lebenyére kiterjedő, korábban reszekálhatatlan májáttétek eltávolítását célozza meg. Ezekben a bonyolult mútétekben a tumormentes szabad szélek (R0-reszekció) eléréséhez a mütét alatti ultrahang nélkülözhetetlen. A májszétválasztás (partition of the liver) a portalis embolizációval együtt soha nem ismert mértékú regenerációt indít el napokon belül az esetek túlnyomó részében (akár 60-84 volumen\%!). A két reszekció közötti várakozási idő akár napokra lecsökken (5-15 nap), és ezáltal az ab ovo nem reszekálható áttéti daganatok reszekabilitási aránya jelentősen növekszik [29]. A két beavatkozás, vagyis a tumor megkisebbítésére irányuló neoadjuváns kezelés és a májparenchyma mennyiségének megnövekedését kiváltó ALPPS egymással egyébként kombinálható. Az is kétségtelen, hogy korai daganatrecidíva és nagyobb morbiditás és mortalitás volt megfigyelhető az ALPPS-t követően, aminek megoldása a jövő feladatának látszik, de ezekben az esetekben kizárólag ez a beavatkozás jelenthette a túlélés meghosszabbítását. A májsebészet és a májtranszplantáció szoros kapcsolata és együttmúködése nélkülözhetetlen, hiszen ha elmarad a nagymértékü regeneráció, vagy mégis májelégtelenség alakul ki, a májtranszplantáció ultimum refugiumként indikált [30].

\section{A vértelen májsebészet és a máj afferens keringésének elzárása}

A májon percenként átáramló 1500-2000 ml vér, a kettős afferens keringés, a vena cava inferior és a 3 vena hepatica bőséges vérárama, valamint az a tény, hogy az esetek 75-80\%-ában cirrhosis és portalis hypertensio áll fenn, továbbá hogy a véralvadás is érintett, a májmütét alatti vérzést, a vérveszteséget és a vérzéscsillapítást a májsebészet kulcskérdésévé tette. A nagy sebészeti beavatkozásnak számító májreszekciós mútét szövődményaránya és halálozása szoros korrelációban van a mütét alatti vérzéssel, a vérveszteséggel és a vérpótlással. A hosszú távú túlélés és a daganatkiújulás is szignifikáns összefüggésben látszik állni a vérveszteség-vérpótlás mértékével [31]. A máj sebészetét múvelők számára mindig is elsőrendû feladat volt a vérzéscsillapítás, amelyet Pringle 1908-ban oldott meg: a ligamentum hepatoduodenale leszorítása megszünteti, illetve minimumra csökkenti a májba beáramló afferens vérkeringést, ezáltal a májreszekciós területből származó vérzés csökkenthető, illetve megszüntethető [32]. Az utóbbi három évtizedben számos egyéb eljárást alkalmaztak a májsebészetben a Pringle-manőveren túlmenően, amelyeknek kizárólagosan az volt a céljuk, hogy a vérzést megelőzzék, illetve megszüntessék: a) különböző módszereket a májparenchyma szétválasztására, b) különböző módszereket a májreszekciós felszín fedésére, c) alacsony centrális vénás nyomás kialakítását, hypoventilatiót, d) anterior reszekciót a konvencionális eljárással szemben, e) gyógyszeres keringésbefolyásolást, f) autotranszfúziót. Lényeges szemléletváltásnak tartható, hogy döntően a preventív szemlélet került a középpontba a vérzéscsillapításban is.

A Cochrane Library-ból a kezdettől 2015 szeptemberéig összegyứjthető és analízisre alkalmas 67 randomizált kontrollált vizsgálat (RCT) metaanalízisével 6197 műtét alapján nem lehetett magas minőségü meggyőző bizonyítékot találni az előbb felsorolt 7 módszer bármelyikének prioritását illetôen [31]. Ezt a tényt támasztja alá, hogy napjainkban a májsebészeti tapasztalat és biztonság soha nem látott megszilárdulása következtében a leghatásosabbnak tartott Pringle-manővert mind kevésbé alkalmazzák a máj sebészetében. Az ischaemiareperfúzió tipikus modellje egyébként is hozzájárulhatott a mütét 
utáni májsejtkárosodásokhoz, noha e kérdésben sok volt az ellentmondó adat [6]. Manapság többszázas, egymás utáni mútétsorozatot közölnek, ahol a Pringle-manővert nem alkalmazzák, és sem a vérzésarány, sem a szövődmények nem emelkednek [33]. A Pringle-manőver újabban még a laparoszkópos májsebészetben is többnyire csak „készenléti állapotban” marad [34]. A májparenchyma átmetszésére a májsebészet ősidők óta használja az ujjmorzsolásos módszert („fringer fracture method”), amelynek Kelly-clamppel (Pean-zúzás) módosított egyszerü, olcsó és biztonságos formáját napjainkban is széles körben alkalmazzák [35].

A májparenchyma szétválasztására a sokféle, fejlett technikát alkalmazó készülék felhasználja energiaforrásként a lézert, az argont, az elektromos áramot, a nagyenergiájú ultrahangot és a rádiófrekvenciát. A leggyakoribb készülékek a Cavitron ultrasonic aspirator (CUSA), a rádiófrekvenciás készülékek, az ultrasonic scalpel, a bipoláris „ragasztó-koaguláló” eszközök és a kliprakók és érvarró gépek. Ezen túlmenően vannak törekvések szöveti ragasztóanyagok, fibrin-, trombinspray alkalmazására a biztonság fokozása és a vérveszteség minimálisra csökkentése érdekében. A jelenlegi helyzet az, hogy a modern májsebészeti gyakorlatban a Pringle-metódus a mindenkori készenléti biztonságot jelenti, ugyanis gyakorlott májsebésznek váratlan, nagy vérzés esetén mindössze néhány másodpercet vesz igénybe az alkalmazása. Ami az egyéb, az előbbiekben felsorolt nagyszámú, modern módszert és készüléket illeti, azokat az adott májsebészeti központ felszereltségétől, gyakorlatától függően a mütéti helyzetnek megfelelően a májsebész az „egyéni judíciumának" megfelelően, az igénytől és a mütéti helyzettől függően kombináltan használja, míg a nagyon egyszerü, közkedvelt és olcsó Pean-zúzásos módszer mindig elérhető, és alapnak számít.

\section{Nyitott, laparoszkópos és robotmájsebészet}

A laparoszkópos májsebészet 1990 és 2000 között kísérleti beavatkozásból a klinikum elfogadott, a nyitott májsebészettel összehasonlítható eljárásává vált. Mind nagyobb és nagyobb számban került be a gyógyító beavatkozások közé, egyre meggyőzőbb eredményekkel. Noha az exponenciálisan növekvő számú publikációk között a hazai adatok is mind gyakrabban fordulnak elö, itthon még nem beszélhetünk arról, hogy a laparoszkópos májreszekció rutineljárássá vált volna $[15,16]$. A laparoszkópos májreszekciók eredményeit összegző és az ajánlásokat megfogalmazó első és második nemzetközi konszenzuskonferencia (Louisville, USA, 2008 és Morioka, Japán, 2014) megállapította, hogy a májon végzett minimálisan invazív beavatkozások: 1) nem maradnak el a nyílt mütétektől, 2 ) számos vonatkozásban előnyösebbek (kisebb vérveszteség), 3 ) onkológiai kompromisszumot sem jelentenek, 4) tapasztalt, begyakorolt májsebészt igényelnek. A világban fennálló helyzetról a Moriokában 2014-ben rendezett konszenzuskonferenci- ára adatokat gyűjtöttek. A 2008 és 2013 közötti időszakot vizsgálták, mely alatt 11712 májreszekció történt 3765 betegen $(32,1 \%)$ laparoszkópos módszerrel. A laparoszkópos májreszekciók $61,8 \%$-a bal lateralis sectionectomia volt. A világirodalomban fellelhető és összehasonlító analízisre alkalmas 9527 laparoszkópos májreszekció eredményei 179 májcentrumból származnak; 65\% történt malignitás miatt. A halálozás $0,4 \%$ volt! Ezen túlmenően 2900, laparoszkóppal mútött beteg adatait eset-összehasonlításra alkalmassá tették a nyitott májreszekcióhoz. A metaanalízisből megállapítható volt, hogy a halálozás nem különbözött, szignifikánsan kevesebb volt a szövődmény, a vérvesztés, a transzfúziós igény - és rövidebb volt a kórházi benntartózkodás a laparoszkópos májreszekció esetén. Az adatokból az is következett, hogy a növekvő betegbiztonság a betegszelekció (indikáció) és a májsebészképzés javulásának következménye.

A randomizált kontrollált vizsgálatok igénye jelentős a forradalmi gyorsasággal széledő minimálisan invazív beavatkozások összehasonlítására, fooként a hagyományos, nyitott technikával végzett beavatkozásokhoz. Az OSLO-COMET tanulmány e vonatkozásban úttörő: 2012 és 2016 között colorectalis reszekábilis májmetasztázis miatt 133 laparoszkópos májreszekció került prospektív összehasonlításra 147 beteg nyitott májreszekciójával: a mútét utáni szövődményráta szignifikánsan alacsonyabb volt, 19 vs. 31\%, és a kórházi benntartózkodás is rövidebb volt laparoszkópos reszekció esetén: 53 vs. 96 óra. Nem észleltek különbséget a mütéti vérvesztésben, a transzfúziós igényben, a daganatmentes reszekciós szél arányában és a 90 napos halálozásban. Az OSLO-COMET vizsgálat fontos megállapítása, hogy az alacsonyabb szövődményarány és a rövidebb kórházi benntartózkodás miatt a költségek azonosak voltak a két csoportban [36]! A laparoszkópos májreszekció indikálható 70 éven felüliek kezelésére is jó betegszelekcióval és kockázatbecsléssel: 225, 70 éven felüli beteg, azonos számú, nyílt reszekcióval összehasonlításra alkalmas adataiból megállapítható volt, hogy a laparoszkópos májreszekció az idősek számára is kevesebb szövődménnyel jár, rövidebb a kórházi benntartózkodás, és nem jelent onkológiai engedményeket a nyitott májreszekcióval történő összehasonlításban [37]. Az onkológiai eredmények vonatkozásában a nagyobb adatbázisokból 1992 és 2016 között összegyűjtött, nem randomizált, de összehasonlíthatóvá tett 4697 beteg adatai figyelemre méltóak: colorectalis rák májáttétei miatt laparoszkópos májreszekció 1809 betegen, míg nyílt mütét 2888-on történt. A laparoszkópos betegcsoportban több volt a tumormentes szabad szél, nem volt szignifikáns különbség a recidíva megjelenési idejében, az 1, 3, és 5 éves teljes túlélésben (OS) és a betegségmentes túlélésben (DFS) $[38,39]$.

A HCC laparoszkópos kezelésének előnyei szintén az alacsonyabb szövődményarányban mutathatók ki, különösen cirrhosis esetén. Multivariációs regressziós analí- 
zissel az egyedüli független tényező a szövődményarány csökkentésében a laparoszkópos beavatkozás [40]. A túlélésben nem mutatható ki eltérés, tehát a laparoszkópos májreszekció onkológiai vonatkozásban is kompetens intervenció.

A robot/robotasszisztált májsebészet már a jelen klinikumának része. Messze nem tekinthető még rutinbeavatkozásnak, azonban a klinikai alkalmasságáról szóló adatok szaporodnak: a 2012 és 2015 között végzett 183 robot-májreszekció átlagos időtartama 434 perc volt, és a hosszabb időtartam ellenére a mútéti vérveszteség átlagosan csak $195 \mathrm{ml}$ volt. A robotmájsebészet elsajátítása tapasztalt májsebész rendszeres, intenzív gyakorlását igényli: 15 beavatkozásig kezdő, 25 elvégeztével középszintű, 50 felett pedig begyakorlott robotvezérlő májsebészről beszélhetünk [4l]. A colorectalis rák és egyidejü májmetasztázisa robot-vastagbélsebész/robotmájsebész munkacsoport együttmúködésével hasonló biztonsággal távolítható el, mint nyílt beavatkozással, és a felépülési idő is rövidebb [42]. A laparoszkópos májsebészet kényes területe a "hátsó-felső" szegmentumok (VII-es, VIII-as, IVa és az l-es szegmentum) minimálisan invazív reszekciója, amely újabban a robotsebészet célkeresztjében is megjelent, méghozzá hasonló kivitelezhetőséggel és biztonsággal [43]. A robotmájsebészettel kapcsolatosan napvilágot látó elemzés szerint a kevesebb szövődmény, a rövidebb intenzív osztályos igénybevétel és a rövidebb kórházi bennfekvés azt a nem várt eredményt hozta, hogy az átlagköltség nem haladta meg a laparoszkópos vagy a nyitott májsebészeti beavatkozás költségét [44].

\section{Szövődmények, rövid és hosszú távú eredmények}

Az új indikációs stratégia, a jobb betegszelekció, a kockázatanalízis, a sebésztechnikai innovációk együttesen a halálozás $1 \%$ alá csökkenését eredményezték a májsebészetben, és a hosszú távú eredmények is jelentősen javultak - a szövődmények gyakoriságát illetően azonban még mindig nagyfokú eltérések tapasztalhatók, 4,1\%$47 \%$ [45].

A modern preventív szemlélet a vérkímélő májsebészet eljárásaiban ölt testet a műtét alatti szövődmények minimalizálására. A vérmentes májsebészet fogalma fedi a koagulációs eltérések mútét előtti rendezését, a minuciózus, koncepciós sebészi technikát, beleértve a minimálisan invazív sebészetet és a vérvesztés megakadályozására szóba jöhető módszerek és eszközök korábban tárgyalt arzenáljának bevetését, különös tekintettel a cirrhoticus májon végzett beavatkozásra. A mütét utáni szövődmények legáltalánosabban elfogadott nemzetközi osztályozása a Clavien-Dindo-féle rendszerrel történt [45]. Azonban éppen a máj diffúz betegségeinek nagyfokú variabilitása, a beavatkozások és azok szövődményeinek nagyszámú változata miatt mind a Clavien-Dindo-rendszer módosítása, mind számos új rendszer látott napvilágot a szövődmények értékelésére, mint az Accordion-szisztéma, továbbá a komprehenzív komplikációs index (CCI) [46]. A komprehenzív komplikációs index valamennyi előforduló szövődményt figyelembe veszi, és a súlyossága szerint is osztályozza. Az adott májműtött betegre vonatkozóan keletkező index a súlyossági skálán értékelendő szenzitív érték, és jól szolgálhat mind a sztenderdizáció, mind a végpont-meghatározás, mind a májon végzett különböző beavatkozások utáni morbiditás összehasonlítására.

Ami a mútétre vonatkozó paramétereket illeti, a mútéti vérveszteség, a mütét alatti vérpótlás mennyisége és a mútéti időtartam feltétlenül összehasonlítható adatot szolgáltat a sebészeti beavatkozás értékelésére! Mütét utáni korai minőségi paraméterek a tumormentes szabad szél (R0-reszekció) aránya, az intenzív terápiás osztályon (respirátoron) töltött idő, a kórházi benntartózkodás időtartama, a Clavien-Dindo szerinti szövődményarány, a 30/90 napon belüli mortalitás és morbiditás, valamint az indokolt kórházi visszautalás mértéke. A klinikum szempontjából a mütét utáni vérzés (hasüregen belüli, tápcsatorna), a májelégtelenség, az epefolyás és epegyülem, valamint az infekciók állnak az előtérben $[47,48]$. Említésre méltó, hogy a májsebészet fejlődése azt eredményezi, hogy a beavatkozások mind szélesebb körben kerülnek alkalmazásra, és a szövődményeket és az eredményeket az a tényező is jelentősen befolyásolja, hogy a májmútét kis (low-volume center) vagy nagy esetszámot (high-volume center) operáló központban történik-e, továbbá mennyire képzettek a májsebészek, és végezetül a „low-volume” centrumból van-e módjuk rendszeres továbbképzésre eljutni nagy esetszámú központba [49].

A colorectalis májáttétek 35-45\%-os 5 éves túlélése ma már elvárható mind a nyitott, mind a laparoszkópos mütétek után. A hosszú távú túlélés bizonyítja, hogy a nyitott és a laparoszkópos mütétek nem különböznek az onkológiai kimenetelben, feltételezve természetesen a metasztázisok neoadjuváns korszerü kemoterápiáját. A korai eredményekben a R0-reszekciók arányában nincs különbség. A késői eredményeket a molekuláris biológia legújabb adatai szerint a KRAS- és a BRAS-mutáció egyaránt negatívan befolyásolja mind a májreszekció utáni teljes túlélésben, mind a betegség (recidíva)-mentes túlélésben [50]. A korszerü onkológiai kezelés (kemoterápia és biológiaiválasz-módosítók) alkalmazható, biztonságos és hatásos a máj mindkét lebenyére kiterjedő, kétszakaszos májreszekciót igénylő eseteire, továbbá a szinkrón májmetasztázisok fennállásakor is. A „borderline"-típusú esetekben a pozitív válasz elmaradásakor a „második vonalbeli” kezelést követően még mindig lehet számítani válaszra bizonyos \%-ban, vagyis a reszekció kivitelezhetőségére kedvező túléléssel [28]. Eleve irreszekábilisnak minősített májáttétek tripla kemoterápiás kezelése (FOLFORINOX) plusz bevacizumab vagy cetuximab kedvezőbben hat a reszekciós arány kialakulására $(44,7,55,6 \%$ !), mint a korábbi terápiás modulok, sőt a teljes túlélés is hosszabb. 
A HCC miatt végzett májreszekció hosszú távú eredményeit a máj alapbetegsége jelentősen befolyásolja, így a cirrhosismentes májrákok 1, 3, 5 éves teljes túlélése 84 , 66 és $50 \%$, a betegségmentes túlélés pedig 69, 53 és $42 \%$ [51]. A cirrhosis talaján kialakult HCC esetén a túlélési értékek messze kedvezőtlenebbek, a reszekció módja (nyitott vagy laparoszkópos mütét) viszont nem befolyásolja sem a teljes, sem a betegség (recidíva)-mentes túlélést [52].

A kisméretű (a milánói kritériumokon belüli) HCCben szenvedő betegeken mind a transzplantáció, mind a reszekció indikálható. 2015 júniusáig a világirodalomból összegyüjtésre és metaanalízisre került valamennyi, a bevételi kritériumnak megfelelt 1431 beteg, akiken reszekció ( 570 beteg), illetve májtranszplantáció ( 861 beteg) történt. Megállapítható volt, hogy a milánói kritériumoknak megfelelő esetekben a májtranszplantáció előnye csak a 10 éves teljes túlélés összehasonlításában jelentkezik, de a májtranszplantáció prioritása már szignifikáns a betegség (recidíva)-mentes 3 éves túlélésben a reszekcióval szemben [53].

\section{A májsebészet jelenlegi szerveződése}

A májsebészet jelenlegi múködése nemzetközi szinten számos vonatkozásban összehangolt, a legfontosabbak az adatgyújtő regiszterek, az irányelvek, a nemzetközi állásfoglalások és az ajánlások [28, 51-57].

A regiszterek közül kiemelendő a LiverMetSurvey, amely 70 ország 313 központjából kapja a májmetasztázisra vonatkozó adatokat analízisre [28]. A májtranszplantáltak adatait az Egyesült Államokban a Scientific Registry of Transplant Recipients (SRTR) gyüjti, és 2016-ra mintegy 187000 beavatkozást volt képes analizálni [54]. A European Liver Transplant Registry 1968 óta múködik, és immáron 145 központból származó adattal dolgozik, külön analizálva az Eurotransplant-országok szervelosztását, a transzplantáció eredményeit (például grafttúlélés) [55]. A várólista-regiszterek (United Network for Organ Sharing) a szervelosztás egyenletességét kívánják megoldani [56]. A számos nemzeti és tudományos társaság kialakította regiszter közös nevezőre hozása kívánatos a közeljövőben.

A nemzetközi és multidiszciplináris együttmúködésben kialakított irányelvek a májsebészet gyors terjedésével és eredményeinek összegzésével egyidejúleg a betegbiztonság és az evidenciaalapú fejlődést szolgálják. Louisville 2008-ban, Morioka 2014-ben és Southampton (Egyesült Királyság) 2017-ben adott helyet a nemzetközileg elismert májsebészeknek, hogy a laparoszkópos májsebészet mind újabb és újabb irányelveit kidolgozzák, továbbá meghozzák azt az állásfoglalást, hogy a laparoszkópos májsebészet biztonságosan alkalmazható a klinikumban, és napjainkban választható rutinbeavatkozássá vált [57]. A máj szekunder daganatainak multimodális kezelését ESMO nemzetközi ajánlás foglalja össze a májsebészet és az onkológia harmonizá- lásával [19]. A HCC-irányelvekre vonatkozóan kétségtelen, hogy a távol-keleti országokban van a legtöbb módosítás, de minden kritika ellenére a világban a legáltalánosabban a barcelonai (BCLC-) irányelv használatos [21].

Az interdiszciplinárisan és nemzetközileg gyorsan szuperspecialitássá fejlődött májsebészetre is igaz, amit a WHO felmérései igazoltak a világ egészségügyével kapcsolatban, hogy jelentős egyenlőtlenségek vannak az elérhetőségben, az ellátásban és az eredményekben az egyes országok között [58]. A jelenlegi törekvések, a regiszterek múködtetése, az adatok analízise, az evidenciák feltárása és a konszenzusirányelvek kidolgozása, a képzés és az akkreditáció sztenderdizálása a májsebészet egyenlőtlenségeinek felszámolását célozzák a jelenben és a jövőben.

Anyagi támogatás: A közlemény megírása anyagi támogatásban nem részesült.

A szerző a cikk végleges változatát elolvasta és jóváhagyta.

Érdekeltségek: A szerzőnek nincs anyagi érdekeltsége.

\section{Irodalom}

[1] Jarnagin WR, Gonen M, Fong Y, et al. Improvement in perioperative outcome after hepatic resection: analysis of 1803 consecutive cases over the past decade. Ann Surg. 2002; 236: 397-406.

[2] Imamura H, Seyama $Y$, Kokudo N, et al. One tousand fifty-six hepatectomies without mortality in 8 years. Arch Surg. 2003; 138: 1198-1206.

[3] Pozzo C, Barone C, Kemeny NE. Advances in neoadjuvant therapy for colorectal cancer with liver metastases. Cancer Treat Rev. 2008; 34: 293-299.

[4] Jakab F, Mersich T. Repeated liver resections as one of the challenge in up-to-date oncologic surgery. [Ismételt májreszekció, a modern daganatsebészet egyik kihívása.] Magy Seb. 2010; 63: 3-8. [Hungarian]

[5] Kupcsulik P. Laparoscopic liver surgery. [Laparoszkópos májreszekciók.] Magy Seb. 2014; 67: 243-251. [Hungarian]

[6] Szijártó A. Free radicals and hepatic ischemia-reperfusion. [Szabad gyökök és máj ischaemiás-reperfúziós károsodása.] Orv Hetil. 2015; 156: 1904-1907. [Hungarian]

[7] Kóbori L, Görög D, Fehérvári I. Progress of liver transplant programme in Hungary. [Májtranszplantációs program fejlódése Magyarországon.] Orv Hetil. 2013; 154: 858-862. [Hungarian]

[8] Bismuth $\mathrm{H}$. Surgical anatomy and anatomical surgery of the liver. World J Surg. 1982; 6: 3-9.

[9] Bismuth H, Eshkenazy R, Arish A. Milestones in the evolution of hepatic surgery. Rambam Maimonides Med J. 2011; 2: e0021.

[10] Friemert B, Franke A, Bieler D, et al. Treatment strategies for mass casualty incidents and terrorist attacks in trauma and vascular surgery. Presentation of a treatment concept. Chirurg 2017; 88: 856-862.

[11] Koós O, Kovács T, Fülöp A, et al. The importance of postoperative circulatory alterations in hepatic surgery. [A posztoperatív keringésváltozások jelentősége a májsebészetben.] Orv Hetil. 2015; 156: 1938-1948. [Hungarian]

[12] Torzilli G, Adam R, Vigano L, et al. Surgery of colorectal liver metastases: pushing the limits. Liver Cancer 2016; 6: 80-90. 
[13] Torzilli G, Vigano L, Gatti A, et al. Twelwe-year experience of "radical but conservative" liver surgery for colorectal metastases: impact on surgical practice and oncologic efficacy. HPB (Oxford) 2017; 19: 775-784

[14] Cieslak KP, Huisman F, Bais T, et al. Future remnant liver function as predictive factor for the hypertrophy response after portal vein embolisation. Surgery 2017; 162: 37-47.

[15] Dede K, Papp G., Salamon F, et al. Laparoscopic resection of a liver metastasis from segment VII. [A máj VII-es szegmentumában igazolt áttéti daganat laparoszkópos reszekciója.] Orv Hetil. 2016; 157: 796-800. [Hungarian]

[16] Mersich T, Sztipics T, Dubóczki Zs, et al. Present situation of minimally invasive liver surgery in the National Institute of Oncology on the basis of the first fifty patients. [A minimálisan invazív májsebészet helyzete az Országos Onkológiai Intézetben - az első 50 beteg kezelésének tapasztalatai.] 7th Congress of Surgical Endoscopic Section of the Hungarian Surgical Society, 2017. október 12-14. Abstract: 45. [Hungarian]

[17] Hu L, Yao L, Li X, et al. Effectiveness and safety of roboticassisted versus laparoscopic hepatectomy for liver neoplasms: A meta-analysis of retrospective studies. Asian J Surg. 2017 Sept 11. DOI: https://doi.org/10.1016/j.asjsur.2017.07.001. [Epub ahead of print].

[18] Chok, KS, Fung JY, Chan AC, et al. Comparable short- and long-term outcomes in living donor and deceased donor liver transplantations for patients with Model for End-stage Liver Disease scores $\geq 35$ in hepatitis-B endemic area. Ann Surg. 2017; 265: 173-177.

[19] Van Cutsem E, Cervanter A, Adam R, et al. ESMO consensus guidelines for the management of patients with metastatic colorectal cancer. Ann Oncol. 2016; 27: 1386-1422.

[20] Zhang EL, Lyang BY, Chen XP, et al. Severity of liver cirrhosis: a key role in the selection of surgical modality for Child-Pugh A hepatocellular carcinoma. World J Surg Oncol. 2015; 13: 148. Doi: 10.1186/s12957-015-0567-9.

[21] Llovet JM, Brú C, Bruix J. Prognosis of hepatocellular carcinoma: the BCLC staging classification. Semin Liver Dis. 1999; 19: 329-338.

[22] Mazzaferro V, Llovet JM, Miceli K, et al. Predicting survival after liver transplantation in patients with hepatocellular carcinoma beyond the Milan criteria: retrospective exploratory analysis. Lancet Oncol. 2009; 10: 35-43.

[23] Burak KW, Kneteman NM. An evidence-based multidisciplinary approach to the management of hepatocellular carcinoma (HCC): the Alberta HCC algorithm. Can J Gastroenterol. 2010; 24: 643-650.

[24] Passot G, Soubrane O, Giuliante F, et al. Recent advances in chemotherapy and surgery for colorectal liver metastases. Liver Cancer 2017; 6: 72-79.

[25] Sturesson C, Valdimarsson VT, Blomstrand E, et al. "Liver first" strategy for synchronous colorectal liver metastases - an intention-to-treat analysis. HPB (Oxford) 2017; 19: 52-58.

[26] Leung U, Gönen M, Allen PJ, et al. Colorectal cancer liver metastases and concurrent extrahepatic disease treated with resection. Ann Surg. 2017; 265: 158-165.

[27] Takemura N, Saiura A: Role of surgical resection for non-colorectal non-neuroendocrine liver metastases (NCNNLM). World J Hepatol. 2017; 9: 242-251

[28] Adam R, Yi B, Innominato PF, et al. Resection of colorectal liver metastases after second-line chemotherapy: is it worthwhile? A LiverMetSurvey analysis of 6415 patients. Eur J Cancer 2017; 78: 7-15.

[29] Oldhafer KJ, Donati M, Jenner RM. ALPPS for patients with colorectal cancer liver metastases: effective liver hypertrophy, but early tumor recurrence. World J Surg. 2014; 38: 1054-1059.

[30] Toso C, Pinto Marques H, Andres A. Liver transplantation for colorectal liver metastasis. Survival without recurrence can be achieved. Liver Transpl. 2017; 23: 1073-1076.
[31] Moggia E, Rouse B, Simillis C, et al. Methods to decrease blood loss during liver resection: a network metaanalysis. Cochrane Database Syst Rev. 2016; 10: CD010683.

[32] Pringle JH. Notes on the arrest of hepatic hemorrhage due to trauma. Ann Surg. 1908; 48: 541-549.

[33] Maurer CA, Walensi M, Käser SA, et al. Liver resections can be performed safely without pringle maneuver: A prospective study. World J Hepatol. 2016; 8: 1038-1046.

[34] Laurenzi A, Cherqui D, Figueroa R, et al. Totally intra-corporeal Pringle maneuver during laparoscopic liver resection. HPB (Oxford) 2018; 20:128-131. [Epub 2017 Nov 24].

[35] Rahbari NN, Elbers H, Koch M, et al. Clamp-crushing versus stapler hepatectomy for transsection of the parenchyma in elective hepatic resections (CRUNSH) - a randomized controlled trial (NTC010449607). BMC Surg. 2011; 11: 22-23.

[36] Fretland AA, Dagenborg VJ, Bjørnelv GM, et al. Laparoscopic versus open resection for colorectal liver metastases: the OSLO-COMET randomized controlled trial. Ann Surg. 2018; 267: 199-207.

[37] Martinez-Cecilia D, Cipriani F, Vishal S, et al. Laparoscopic versus open liver resection for colorectal metastases in elderly and octogenarian patients: a multicenter propensity score based analysis of short- and long-term outcomes. Ann Surg. 2017; 265: 1192-1200.

[38] Xie SM, Xiong JJ, Lju XT. Laparoscopic versus open liver resection for colorectal liver metastases: a comprehensive systematic review and meta-analysis. Sci Rep. 2017; 7: 1012. Doi: 10.1038/ s41598-017-00978-z.

[39] Hallet J, Beyfuss K, Memeo R, et al. Short- and long-term outcomes of laparoscopic compared to open liver resection for colorectal metastases. Hepatobiliary Surg Nutr. 2016; 5: 300-310.

[40] Sposito C, Battiston C, Faccirusso A, et al. Propensity score analysis of outcomes following laparoscopic or open liver resection for hepatocellular carcinoma. Br J Surg. 2016; 103: 871-880.

[41] Chen PD, Wu CY, Hu RH, et al. Robotic major hepatectomy: is there a learning curve? Surgery 2017; 161: 642-649.

[42] Xu J, Wei Y, Ye Q, et al. Robotic procedure versus open surgery for simultaneous resection of colorectal cancer with liver metastases: short-term outcomes of a randomized controlled study. J Clin Onc. 2017; 35(15 Suppl): 3575.

[43] Montalti R, Scuderi V, Patriti A, et al. Robotic versus laparoscopic resections of posterosuperior segments of the liver: a propensity score-matched comparison. Surg Endosc. 2016; 30: 1004-1013.

[44] Daskalaki D, Gonzalez-Heredia R, Brown M, et al. Financial impact of the robotic approach in liver surgery: A comparative study of clinical outcomes and costs between the robotic and open technique in a single institution. J Laparoendosc Adv Surg Tech A 2017; 27: 375-382.

[45] Katayama H, Kurokawa Y, Nakamura K, et al. Extended Clavien-Dindo classification of surgical complications: Japan Clinical Oncology Group postoperative complications criteria. Surg Today 2016; 46: 668-685.

[46] Clavien PA, Vetter D, Staiger RD, et al. The Comprehensive Complication Index $\left(\mathrm{CCI}^{\circledR}\right)$ : added value and clinical perspectives 3 years "down the line". Ann Surg. 2017; 265: 1045-1050.

[47] Cherqui D, Soubrane O. Laparoscopic liver resection: an ongoing revolution. Ann Surg. 2017; 265: 864-965.

[48] Ulyett S, Shahtahmassebi G, Aoori S, et al. Comparison of riskscoring systems in the prediction of outcome after liver resection. Perioper Med (Lond). 2017; 6: 22. Doi: 10.1186/s13741-0170073-4.

[49] Nygård IE, Lassen K, Kjæve J, et al. Mortality and survival rates after elective hepatic surgery on a low-volume centre are comparable to those of high-volume centre. ISRN Surg. 2012; 2012: 783932.

[50] Tosi F, Magni E, Amatu A, et al. Effect of KRAS and BRAF mutations on survival of metastatic colorectal cancer after liver 
resection: A systematic review and meta-analysis. Clin Colorectal Cancer 2017; 16: e153-el63.

[51] Thelen A, Benckert C, Tautenhahn HM, et al. Liver resection for hepatocellular carcinoma in patients without cirrhosis. Br J Surg. 2013; 100: 130-137.

[52] Yamashita Y, Ikeda T, Kurihara T, et al. Long-term favorable surgical results of laparoscopic hepatic resection for hepatocellular carcinoma in patients with cirrhosis: a single-center experience over a 10-year period. J Am Coll Surg. 2014; 219: 1117-1123.

[53] Menahem B, Lubrano J, Duvoux C, et al. Liver transplantation versus liver resection for hepatocellular carcinoma in intention to treat: An attempt to perform an ideal meta-analysis. Liver Transpl. 2017; 23: 836-844.

[54] Yanik EL, Nogueira LM, Koch L, et al. Comparison of cancer diagnoses between the US solid organ transplant registry and linked central cancer registries. Am J Transplant. 2016; 16: 2986-2993

[55] Jochmans I, van Rosmalen M, Pirenne J, et al. Adult liver allocation in Eurotransplant. Transplantation 2017; 101: 1542-1550.
[56] Alver SK, Lorenz DJ, Washburn K, et al. Comparison of two equivalent model for end-stage disease scores for hepatocellular carcinoma patients using data from the United Network for Organ Sharing liver transplant waiting list registry. Transpl Int. 2017; 30: 1098-1109.

[57] Abu Hilal M, Aldrighetti L, Dagher I, et al. The Southampton Consensus Guidelines for Laparoscopic Liver Surgery: From Indication to Implementation. Ann Surg. 2017 Oct 23. Doi: 10.1097/SLA.0000000000002524. [Epub ahead of print]

[58] Dahlgren G, Whitehead M. European strategies for tackling social inequalities in health: Levelling up, Part 2. World Health Organisation, Regional Office for Europe, Copenhagen. WHOLIS E89384, 2007.
(Jakab Ferenc dr., Budapest, Uzsoki u. 29., 1145 e-mail: jakab@uzsoki.hu)

\section{NOTA}

\section{Új fejlesztés az egészségügyben dolgozók, tanulók részére!}

A magyar nyelvứ szakirodalmi keresőszolgáltatás

\section{Mi a NOTA? \\ Napivizit Orvosi Tudástár Alkalmazás}

Mit tud a NOTA portál?

Megkönnyíti a magyar nyelvű szakirodalmi források keresését.

Eszköztöl függetlenül, akár okostelefonról, a betegágy mellett állva is használható.

\section{Miben kereshet a NOTA-val?}

Az Akadémiai Kiadó folyóirataiban: Orvosi Hetilap, Magyar Sebészet, Mentálhigiéné és Pszichoszomatika.

\section{Más kiadók magyar nyelvü}

szakfolyóirataiban: pl. Lege Artis

Medicinae, Hypertonia és Nephrologia, Ideggyógyászati Szemle.

A hatályos szakmai irányelvekben.

Magyar nyelvű kérdésekre adott ango nyelvű találatokban, a PubMeden.

\section{nota.hu}

Amennyiben további információra lenne szüksége, keressen minket elérhetőségeinken:

journals@akademiai.hu /hirdetes@akademiai.hu

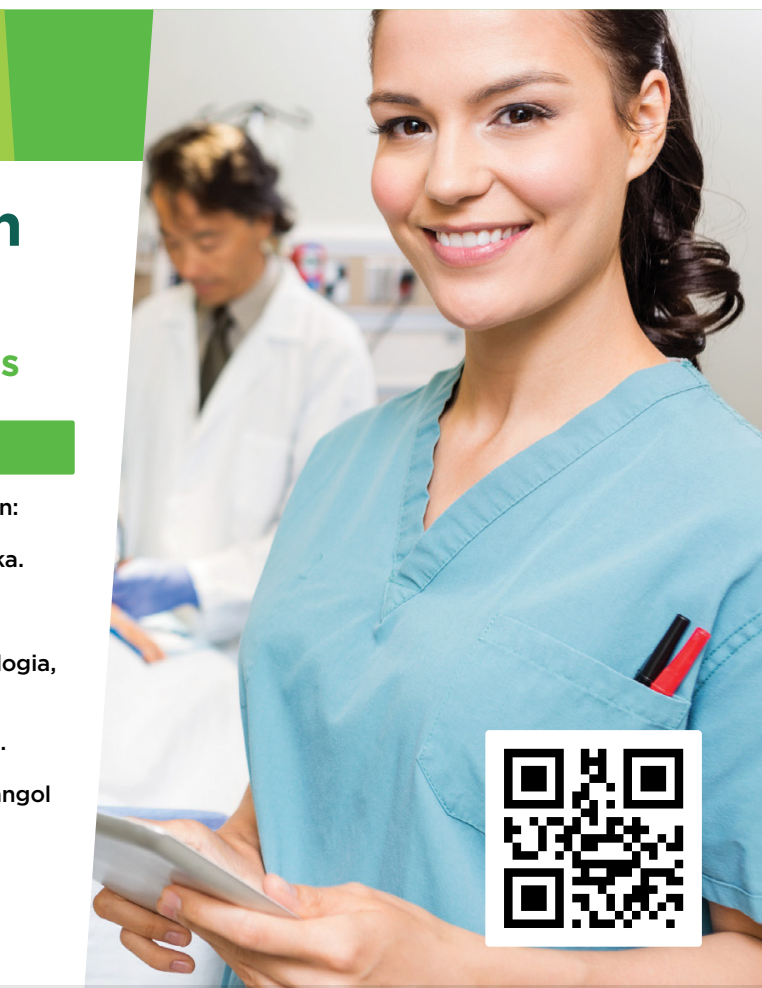

\section{Akadémiai Kiadó}

A Wolters Kluwer Csoport tagja

1117 Budapest, Prielle Kornélia u. 21-35. / Telefon: (1) 464-8246 www.akademiai.hu / www.akademiai.com

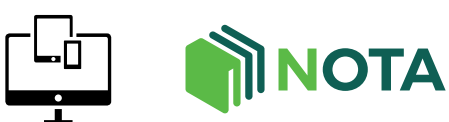

AKADÉMIAI KIADÓ 